\title{
On the taxonomy of Apollonias Nees (Lauraceae). Evidence from general aspects and cuticular features of leaf $\&$ fruit.
}

\author{
Mohammed H. A . Loutfy \\ Biological Science and Geology Department. \\ Faculty of Education. Ain Shams University. \\ Roxy (Heliopolis) P.C. 1134. Cairo. Egypt.
}

\begin{abstract}
Loutfy M. H. A. 2001. On the taxonomy of Apollonias Nees (Lauraceae). Evidence from general aspects and cuticular features of leaf \& fruit. Taeckholmia 21(1): 59-80.

Leaf and fruit cuticular features (cell form and / or epicuticular secretions) were studied in the Macaronesian endemic tree Apollonias barbujana (cav.)Bornm. using SEM and / or LM. In addition, the macromorphological and floristic aspects of the genus were surveyed. The results were then compared with similar features in 19 available taxa of the Lauraceae representing the tribes Laureae and Perseeae (Five taxa from the present study and 14 compiled from Literature). The data obtained were analyzed by the NT sys- pc program package using the UPGMA clustering method. The produced dendrograms were discussed. The study showed that Apollonias occupies a relatively isolated position in the family with affinities to both the Laureae and the Perseeae. The significance of cuticular features in the taxonomy of the Lauraceae was referred to, and a revision of the suprageneric classification of the family as suggested by Rohwer, 2000 is now strongly supported.
\end{abstract}

Key words: Apollonias, cuticle, Lauraceae, SEM.

\section{Introduction}

Lauraceae (50 genera and 2500 species sensu Mabberley 1997) is a monophyletic family dating back at least to the mid-Cretaceous (Rohwer, 1993 \& 2000). Yet, the relationships between its genera and species are still poorly understood mainly because many of its taxa are either still unknown (with new ones still discovered and identified from tropical and uninhabited regions worldwide), or are high forest trees with inconspicuous flowers difficult to locate and to collect; thus offering scanty material for research (Van der Werff \& Richter, 1996 and Rohwer, 2000). Van der Werff (1991) showed that artificial generic and specific boundaries are common in the family due to convergent evolution, thus making generic delimitation problematic.

Apollonias (Tribe Perseeae sensu Rohwer, 1993) was named by Nees (1833) who then described in 1836 two species, viz. A. arnottii from India (known only from the Type) and $A$. canariensis from Macaronesia; later amended to A. barbujana (Cav.) Bornm; (Bornmuller, 1903). However, Rohwer (1993 \& 2000) has questioned the actual existence of the Indian species Apollonias arnottii Nees, he believed that Apollonias can be considered as a monotypic genus. 
Apollonias barbujana (Cav.) Bornm.( Type species assigned by Farr et al; 1979) is a Macaronesian endemic taxon and constitute together with few Lauraceous genera, a Tertiary relict plant formation ( Last representative of the ancient Tethyan forests) that was once widespread in the Mediterranean region some 20 million years ago (Press \& Short, 1994).

The taxonomy of $A$. barbujana and its relationships with other genera in the Lauraceae were controversial. Baillon (1872), considered it to be very near to Cinnamomum Burm, s.str. regarding its floral structure and to Phoebe Nees regarding its fruits, yet distinguished from both, by its bilocular anthers. Kostermans (1957) considered Apollonias to be very near Persea Mill. and has probably arised from it through Phoebe Nees. Richter (1981), proposed a classification for Lauraceae based primarily on wood and bark anatomy, where Apollonias stands the same distance apart from two groups : the first one corresponds with the tribe including involucrate inflorescences (Tribe Laureae sensu Kostermans 1957 and Rohwer, 1993 ) and the other corresponds to the tribes Cinnamomeae and Perseeae (sensu Kostermans, 1957)or the Perseeae (sensu Rohwer, 1993) with ex- involucrate inflorescences.

Rohwer (1993), suggested that Apollonias should be included in Phoebe Nees. The same author (2000) after a cladistic analysis based on evidence from mat $\mathrm{K}$ sequences, showed that Apollonias together with Alseodaphne Nees, Dehaasia Blume, Persea Mill. and Phoebe Nees seem to constitute a real phylogenetic alliance, which he called the Persea group, while Cinnamomum Schaeff (s.l.) appeared distant.

Van der Werff \& Richter (1996), stressed on the utmost importance of incorporating new data sets from different criteria in order to achieve more conclusive results about the interrelationships within the Lauraceae eventually cuticular studies, molecular aspects, phytochemestry, etc.

Cuticular studies in the Lauraceae were used by many authors in an attempt to differentiate between species or to clarify the relations between them (Bandulska, 1926; Kasapligil, 1951; Ferguson, 1971\&1974; Hill, 1986; Ow et al, 1992). However, Christophel et al. (1996a), Christophel \& Rowett (1996b) and Li \& Christophel (2000) drew the attention to the importance of cuticular features in the taxonomy of the Lauraceae. Furthermore, they stressed on the fact that the family makes an ideal candidate for a global study based on leaf cuticles.

As to Apollonias barbujana, the subject of the present study, no studies were made on its leaf cuticular features except a scanty report given by Ferguson (1974) who showed that herbarium specimens of Apollonias and Laurus (that were often confused), could be distinguished from each other only by the leaf epidermal anticlinal cell walls which are generally straight in the former taxon and are sinnuate to slightly undulate in the latter taxon. Kamel \& Loutfy (in press) made a preliminary LM investigation of the leaf cuticles of eight Lauraceous taxa including Apollonias barbujana. Yet, further studies on more cosmopolitan material of the Lauraceae are still needed before a firm conclusion could be drawn. This fact was surveyed by Graybeal (1998) who showed that more accuracy and a better resolution of the produced dendrograms were much higher, if the constant characters were distributed across a larger number of taxa. 


\section{Materials and Methods}

In the present work, macromorphological and floral aspects of Apollonias barbujana are investigated, while SEM and / or light microscopy of cuticular features were surveyed and compared with the same features in 19 available taxa of the Lauraceae. (Five of these taxa were introduced to Egypt in the late nineteenth century, information of the other 14 taxa were compiled from Christophel et al., (1996a); Christophel \& Rowett,(1996b); Li \& Christophel,(2000) and Loutfy, (2000).

The studied taxa, along with the compiled ones belong to 12 genera and two tribes, viz. Laureae and Perseeae sensu Rohwer, (1993); and / or the three tribes of the family, viz. Laureae, Perseeae and Cryptocaryeae sensu Van der Werff \& Richter, (1996). Care has been taken to select taxa covering a global geographical range in both the Old and the New World.

In addition, a preliminary LM investigation of the fruit cuticle of Apollonias barbujana was made and then compared with the available fruit cuticles of certain taxa in the Lauraceae collected from Egypt (one species of Laurus, two species of Cinnamomum and two subspecies of Persea americana).

For creating a data matrix for numerical analysis of the results, the recorded characters as well as the compiled ones were analyzed by the NTsys-pc. program package, using the UPGMA clustering method. The dendrogram produced was discussed in the light of the current systems of classification of the Lauraceae (Kostermans, 1957; Richter, 1981; Rohwer, 1993; Van der Werff \& Richter, 1996 and Rohwer, 2000).

The examined species, their sources or origin, in addition to the compiled data of other taxa and their sources are listed in Table (1). Voucher specimens of the examined species are kept at the Department of Biological Sciences. Faculty of Education, Ain Shams University. Macromorphological aspects were studied from fresh and / or herbarium specimens, as well as from relevant literature (Baillon, 1872; Kostermans, 1957; Bailey \& Bailey, 1976; Rohwer, 1993 \& 1994 and Short, 1994). For the study of leaf surface using the SEM, three leaves for each species were dehydrated, then mounted in colloidal silver on copper stubs and coated with a thin layer of gold in Polaron E 5000 . The leaf epidermis was then photographed by a Jeol - Scanning Electron Microscope at the Central Lab of Faculty of Science, Alexandria University. Fruit epidermal cells were examined in epidermal peels stained with either 1\% aquous safranin and photographed using a Carl-Zeiss Photomicroscope ш.

For the data analysis, the total number of the recorded characters in each taxon were scored, combined together in three sets of data and coded for creating the data matrix for computation. The relationships between the studied taxa, expressed by average taxonomic distance (dissimilarity), was demonstrated as phenograms, based on the analysis of the recorded characters using the NT-sys program package for IBM - pc. as described by Rohlf (1993). 
M. H. A Loutfy

Table 1, The investigated Taxa; their sources, systematy and geographical distribution.

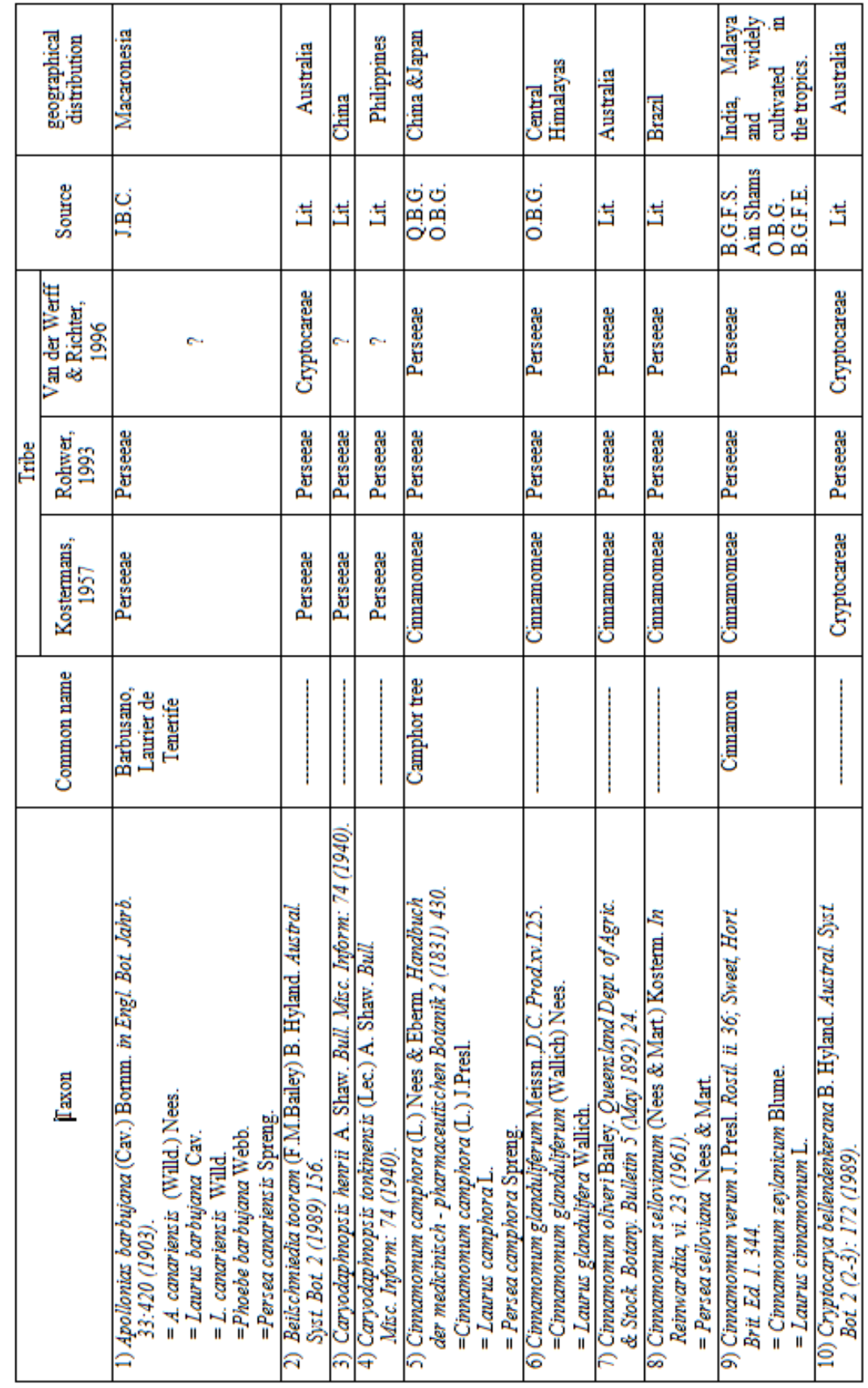


On the taxonomy of Apollonias.Evidence from general aspects and cuticular features of leaf \& fruit.

Table 1, continued.

\begin{tabular}{|c|c|c|c|c|c|c|c|c|}
\hline 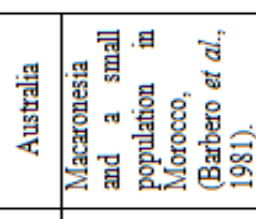 & 昜 & & $\begin{array}{l}\text { 查 } \\
\text { 嘉 }\end{array}$ & 罗 & 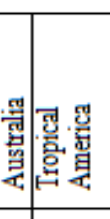 & 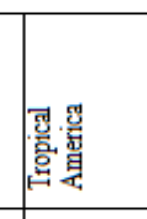 & & 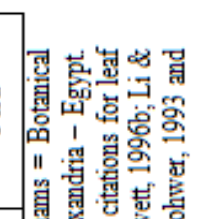 \\
\hline 䓀洁 & : & 莟 & 苛 & 莒 & & & & $\mid \begin{array}{l}\frac{1}{4} \\
0.0 \\
0.0\end{array}$ \\
\hline 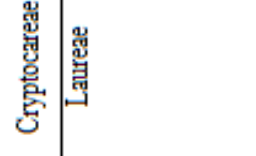 & 总 & & 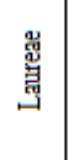 & 蠋 & & 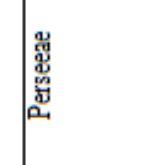 & & 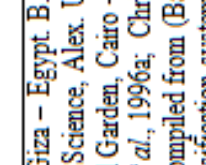 \\
\hline 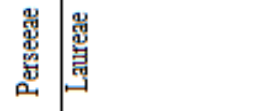 & 黗 & & 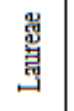 & 总 & 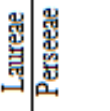 & 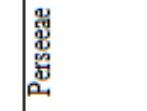 & & 昜 \\
\hline 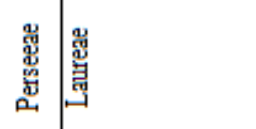 & 崖 & & & 菢 & 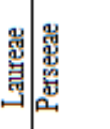 & 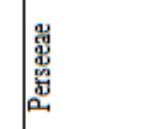 & & 買 \\
\hline 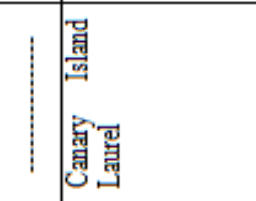 & 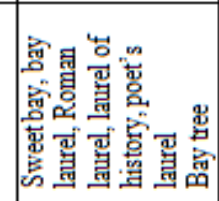 & & & 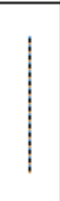 & 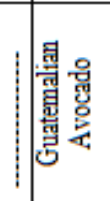 & 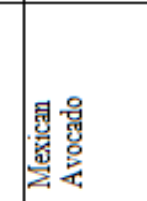 & & \\
\hline 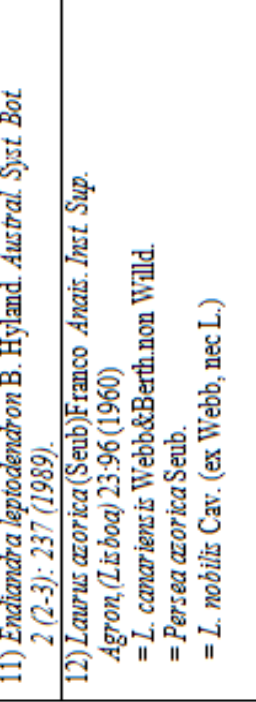 & 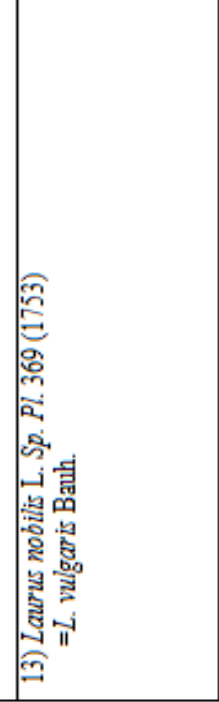 & 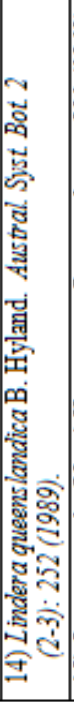 & 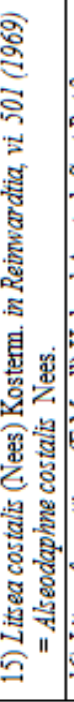 & & 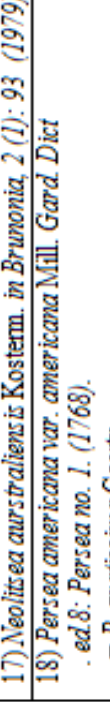 & 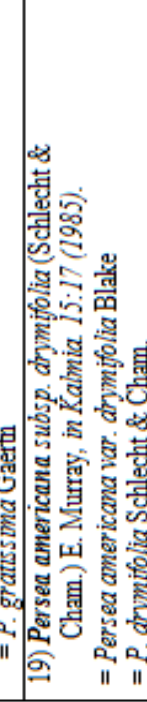 & & 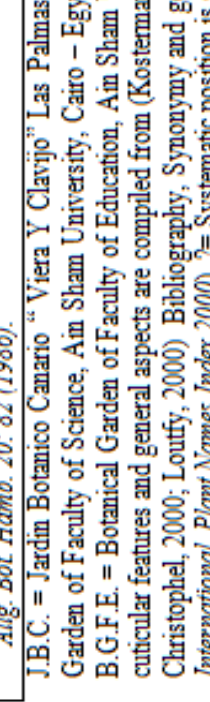 \\
\hline
\end{tabular}




\section{Results}

Apollonias barbujana (Cav.) Bornm. (Fig. 1) is a slow growing evergreen tree up to $25 \mathrm{~m}$, with a dense rounded crown.
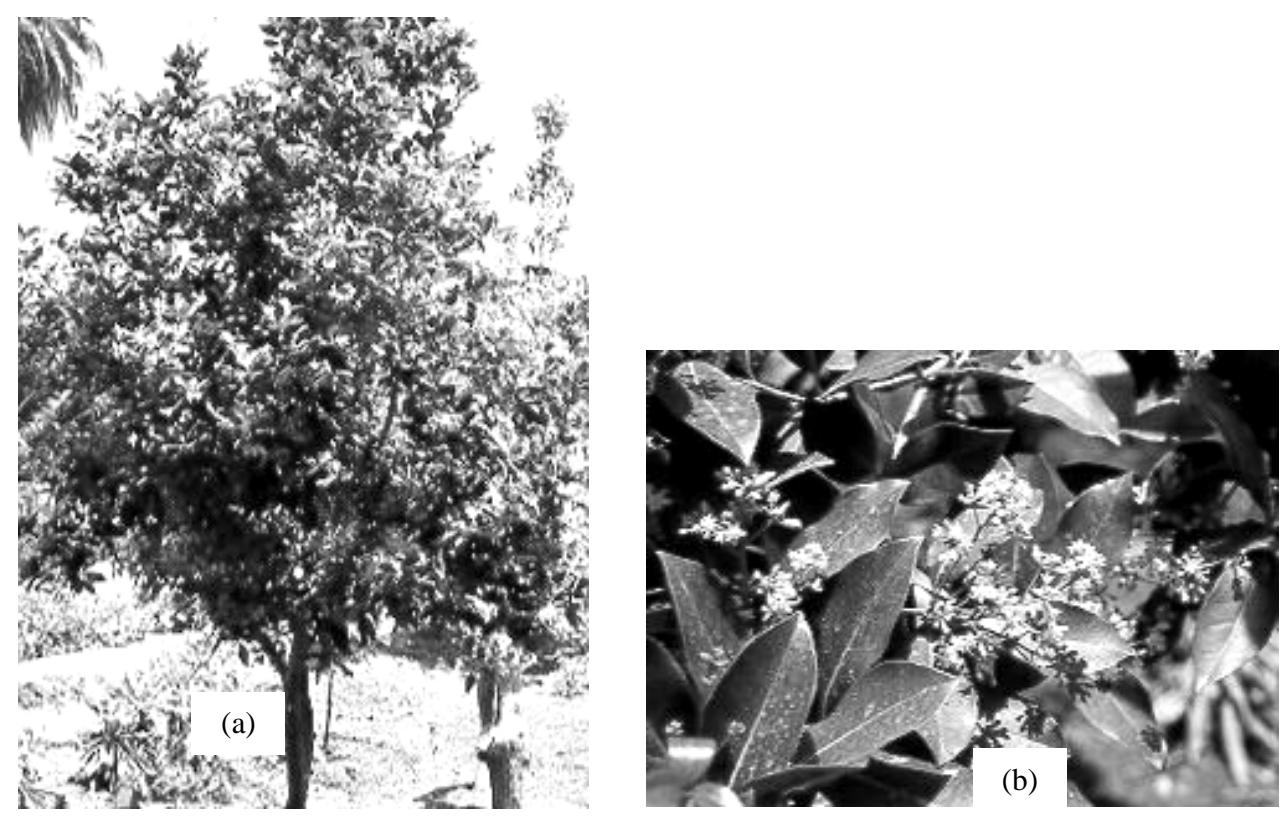

Figure1. Apollonias barbujana (Cav.) Bornm. a-Habit of tree. b-Flowering branches. From: A:\APOLLONIAS BARBUJANA. htm

\section{Macromorphological diagnostic characters (Table 2 a)}

Twigs glabrous. Leaves alternate, peninerved, very stiff, 5-15 x 2.5 cms., elliptic with an acute to obtuse apex. Margins revolute or entire, dark glossy green, glabrous; petioles. 5-1.3 cms., glabrous, cuneiform in cross- section (Kamel \& Loutfy, in press). Inflorescences thyrsopaniculate. Peduncles up to $3 \mathrm{~cm}$. glabrous. Flowers trimerous, bisexual. Tepals sub-equal (outer whorl smaller). 3 - $4.5 \mathrm{~mm}$., oblong, ovate, acute to obtuse, greenish white. Fertile stamens 9, the third whorl \pm extrose. Anthers 2- locular; staminodes of whorl 4 conspicuous, sagitate stiptate, receptacle very small and flat; fruit, a berry $1.5-2 \mathrm{cms}$. ellipsoid, clasped at the base by the persistent perianth segments, dull green, turning black when ripe. Seed ellipsoid, $0.5 \times 0.5 \times 1 \mathrm{cms}$. with a thin testa and two large cotyledons (Rohwer, 1993b and Short, 1994). 
On the taxonomy of Apollonias.Evidence from general aspects and cuticular features of leaf \& fruit.

Table (2a). Macromorphological and floral aspects of the studied and the compiled taxa.

\begin{tabular}{|c|c|c|}
\hline Characters & Attributes & Species numbers \\
\hline \begin{tabular}{|l} 
Leaf venation \\
\end{tabular} & $\begin{array}{l}\text { 1.Penninerved. } \\
\text { 2.Penninerved showing strengthened } \\
\text { basal secondary veins. } \\
\text { 3.Triplinerved. }\end{array}$ & $\begin{array}{l}\text { 1,2,7,11,12,13,14,15,16,18,19,20. } \\
\text { 5,6,8,10,17. } \\
\text { 3,4,9. }\end{array}$ \\
\hline $\begin{array}{l}\text { Inflorescence } \\
\text { a-Type }\end{array}$ & $\begin{array}{l}\text { Thyrsopaniculate (starting with a recemose } \\
\text { branching pattern, but are cymose in their } \\
\text { distal parts). } \\
\text { Botryoid (Psuedo umbels arranged in a } \\
\text { condensed raceme). } \\
\text { Thyrsopaniculate to botryoid. } \\
\text { b.1. Present. } \\
\text { b.2. Absent. }\end{array}$ & $\begin{array}{l}\text { 1,2,5,6,7,8,9,10,18,19,20. } \\
\text { 12,13,14,15,16,17. } \\
\text { 3,4,11. } \\
\text { 12,13,14,15,16,17. } \\
\text { 1,2,3,4,5,6,7,8,9,10,11,18,19,20 }\end{array}$ \\
\hline Flower & $\begin{array}{l}\text { 1.Bisexual. } \\
\text { 2.Unisexual by abortion. }\end{array}$ & $\begin{array}{l}1,2,3,4,5,6,7,8,9,10,11,18,19 . \\
12,13,14,15,16,17,20 .\end{array}$ \\
\hline $\begin{array}{l}\text { Androecium } \\
\text { a.Fertile stamens. }\end{array}$ & $\begin{array}{l}\text { a.1.Three . } \\
\text { a.2. More . }\end{array}$ & $\begin{array}{l}11 . \\
\text { the rest of the studied taxa. }\end{array}$ \\
\hline $\begin{array}{l}\text {.Third whorl (or } \\
\text { inner whorls in } \\
\text { taxa with more } \\
\text { than } 9 \text { fertile } \\
\text { stamens) } \\
\text { c.Anther locules }\end{array}$ & $\begin{array}{l}\text { b.1.Basically extrose. } \\
\text { b.2. Basically entrose. } \\
\text { c.1.Two locular. } \\
\text { c.2 Four.locular. } \\
\text { c.3. Varying. }\end{array}$ & $\begin{array}{l}\text { 1,2,10,11,12,13,14. } \\
\text { 3,4,5,6,7,8,9,15,1617,20. } \\
\text { 18,19. }\end{array}$ \\
\hline Receptacle & $\begin{array}{l}\text { 1.Small and flat. } \\
\text { 2.Small, shallowly cup shaped. } \\
\text { 3.Flat to cup shaped. } \\
\text { 4.Deeply urceolate. } \\
\text { 5.Narrowly tubular. }\end{array}$ & $\begin{array}{l}\text { 1,3,4,12,13,14,16,18,19. } \\
5,6,7,8,9 . \\
2,11,15,16 \\
10 . \\
20 .\end{array}$ \\
\hline Fruit & $\begin{array}{l}\text { Free on a scarcely enlarged pedicel. } \\
\text { Free, its base clasped by the persistent perianth } \\
\text { segments. } \\
\text { With a cupule of various shapes. } \\
\text { Completely enclosed in the accrescent } \\
\text { receptacular tube. }\end{array}$ & $\begin{array}{l}\text { 2,3,4,11,18,19. } \\
1 . \\
5,6,7,8,9,12,13,14,15,16,17,20 . \\
10 .\end{array}$ \\
\hline
\end{tabular}




\section{SEM and / or light Microscopy of leaf and fruit cuticle of Apollonias barbujana}

\subsection{Leaf cuticle}

\section{Upper epidermis}

Epidermal cells from a reticulate pattern, devoid of any stomata. Cells angular to rounded. Anticlinal walls thick, raised, slightly undulate to straight and striated. Periclinal walls slightly concave and granular. Tertiary sculpture on the epidermal cells appears as dense epicuticular waxes, covering the whole surface particularly on the anticlinal walls and observed as clusters of hollow tubules (Fig.2 a-c, Table 2b).

\section{Lower epidermis}

Epidermal cells from an irregularly reticulate pattern, Anticlinal walls undulate, thick and raised, with a slightly buttressed thickening pattern. Periclinal walls appear granular to papillose. Stomata paracytic (Rubiaceous), subsidiary cells take the characteristic shape of the guard cells observed in other families, while the true guard cells are not obvious and sunken (a synapomorphy that unites the Lauraceae worldwide, Hill, 1986 and Christophel \& Rowett, 1996 b), cuticular ledges are butterfly shaped (Kamel \& Loutfy, in Press). Epicuticular waxes are seen as clusters of short hollow tubules, intermingled with entire platelets (Fig.2 d-f,Table 2b).

\subsection{Fruit cuticle}

Epidermal cells are highly sinuate. Anticlinal walls extremely thick and sinuate. Periclinal walls flat and smooth (Fig.3 a\&b , Table 2c).

\section{Macromorphological and floral aspects of the examined taxa}

As to the macromorphological and floral aspects of the compaired taxa; only the attributes that are / or were considered to be of taxonomic significance by different authors are summerized and compared in Table 2a.

\section{Leaf cuticular features of the studied and the compiled taxa}

Cuticular futures are sumerized in Table $2 \mathrm{~b}$, the taxa are numbered 1-20 as presented in Table (1). Terminology is taken after (Wilkinson, 1979; Barthlott, 1981 \& 1990; Stearn 1992; Christophel \& Rowett, 1996b and Barthlott et al 1998). 
On the taxonomy of Apollonias.Evidence from general aspects and cuticular features of leaf \& fruit.

Table (2b). Leaf cuticular aspects of the studied and the compiled taxa.

\begin{tabular}{|c|c|c|}
\hline Characters & Attributes & Species numbers \\
\hline $\begin{array}{l}\text { Upper epidermis } \\
\text { a.Cell shape. }\end{array}$ & $\begin{array}{l}\text { 1.Rounded. } \\
\text { 2.Angular. } \\
\text { 3.Angular torounded. } \\
\text { 4.Sinuate. } \\
\text { 5.Undulate to sinuous. }\end{array}$ & $\begin{array}{l}10 . \\
2,5,6,11 \\
1,3,4,8,15,16,18,19,20 \\
7,9,12,13 \\
14,17\end{array}$ \\
\hline b.Anticlinal walls. & $\begin{array}{l}\text { Shape:- } \\
\text { 1.Straight. } \\
\text { 2.Slightly undulate. } \\
\text { 3.Sinuate. } \\
\text { Thickness degree:- } \\
\text { 1.Thick. } \\
\text { 2.Variable, } \\
\text { 3.Thin, } \\
\text { Pattern of thickening:- } \\
\text { 1.Smooth(uniform). } \\
\text { 2.Beaded. } \\
\text { 3.Buttressed. } \\
\text { 4.Slightly beaded to smooth. } \\
\text { Secondary sculpture:- } \\
\text { 1.Striated. } \\
\text { 2.Smooth. }\end{array}$ & $\begin{array}{l}2,5,6,11,18,19 . \\
1,3,4,8,15,16,20 . \\
7,9,12,13,14,17 . \\
1,12,13 . \\
\text { 10,15,16,17. } \\
\text { the rest of the studied taxa. } \\
1,3,4,5,6,7,10,11,14,18,19 . \\
8 . \\
2,9,12,13 . \\
15,16,17,20 . \\
1,12,13 . \\
\text { the rest of the studied taxa. }\end{array}$ \\
\hline c.Periclinal walls. & $\begin{array}{l}\text { Level:- } \\
\text { 1.Slightly concave to flat. } \\
\text { 2.Convex to flat. } \\
\text { 3. More or less flat. } \\
\text { Texture:- } \\
\text { 1.Straight to finely granular. } \\
\text { 2.Granular. } \\
\text { 3.Granular punctate. } \\
\text { 4.Finely granular to papillose. } \\
\text { 5.Granular with glandular bodies prominent, } \\
\text { 6. Irregularly thickened. } \\
\text { 7.Smooth. } \\
\text { 8.Smooth to finely granular. }\end{array}$ & $\begin{array}{l}1,12,13,14,18,19 . \\
10 . \\
\text { the rest of the studied taxa } \\
7,12,13 . \\
3,4,15,16,17 . \\
6,8,18,20 \\
1,5,6,9,10 . \\
19 . \\
2 . \\
11 . \\
14 .\end{array}$ \\
\hline $\begin{array}{l}\text { d.Epicuticular } \\
\text { wax. }\end{array}$ & $\begin{array}{l}\text { Shape:- } \\
\text { 1.Clusters of tubules. } \\
\text { 2.Syntopism of platelets and rodlets. } \\
\text { 3.Syntopism of platelets and transversely ridged } \\
\text { rodlets. } \\
\text { 4. Crusts. } \\
\text { 5.Curled rods \& short filaments. } \\
\text { 6.Coarse globules, warts, small rods. } \\
\text { lll defined:- }\end{array}$ & $\begin{array}{l}1 . \\
5,6,18 . \\
9 . \\
19 . \\
13 . \\
12 . \\
\text { the rest of the studied taxa. }\end{array}$ \\
\hline $\begin{array}{l}\text { Lower epidermis } \\
\text { a.Cell shape }\end{array}$ & $\begin{array}{l}\text { 1.Irregular to rounded. } \\
\text { 2.Angular to rounded. } \\
\text { 3.Angular. } \\
\text { 4.Sinuate. } \\
\text { 5.Undulate to sinuous. }\end{array}$ & $\begin{array}{l}\text { 1,3,4,5,6,10,16,18,19. } \\
11,15 . \\
20 . \\
7,9,12,13,14 . \\
2,8,17 .\end{array}$ \\
\hline
\end{tabular}


Table (2b). continued.

\begin{tabular}{|c|c|c|}
\hline Characters & Attributes & Species numbers \\
\hline b.Anticlinal walls & $\begin{array}{l}\text { Shape:- } \\
\text { 1.Straight. } \\
\text { 2.Slightly undulate. } \\
\text { 3.Sinuate. } \\
\text { 4. Undulate to sinuous. } \\
\text { Thickness:- } \\
\text { 1.Thick, } 1,2,9,10,12,13 ; \\
\text { 2.Slightly thick: } \\
\text { Pattern of thickening:- } \\
\text { 1.Buttressed. } \\
\text { 2.Slightly buttressed. } \\
\text { 3.Ridged to buttressed. } \\
\text { 4.Irregular. } \\
\text { 5.Smooth (uniform). } \\
\text { 6.Smooth to finely beaded. } \\
\text { 7.Smooth to buttressed. } \\
\text { 8.Beaded. } \\
\text { Hight:- } \\
\text { 1.Highly raised. } \\
\text { 2.Raised. } \\
\text { Secondary sculpture (Texture):- } \\
\text { 1.Striated. } \\
\text { 2.Smooth. }\end{array}$ & $\begin{array}{l}\text { 5,6,18,19,20. } \\
1 . \\
7,9,12,13,14 . \\
2,8,17 . \\
\text { 1,2,9,10,12,13. } \\
\text { the rest of the studied taxa. } \\
\\
9,12,13 . \\
1 . \\
2 . \\
3,4,5,6,18 . \\
7,8,15,16,19,20 . \\
10,11 . \\
14 . \\
17 . \\
11,12,13,16 . \\
\text { the rest of the studied taxa. } \\
\text { 3,4,10,12,13,14,16,17. } \\
1,2,5,6,7,8,9,11,15,18,19,20\end{array}$ \\
\hline c.Periclinal walls & $\begin{array}{l}\text { Level:- } \\
\text { 1.Flat to slightly convex. } \\
\text { 2.Slightly concave: } \\
\text { Texture:- } \\
\text { 1.Granular to papillose. } \\
\text { 2.Finely striated. } \\
\text { 3.Papillose. } \\
\text { 4.Smooth. }\end{array}$ & $\begin{array}{l}10 . \\
\text { the rest of the studied taxa. } \\
1,3,4,5,6,7,8,9,18,19 \text {. } \\
10,12,13,14,15,16,17 \\
20 . \\
2,11 \text {. }\end{array}$ \\
\hline $\begin{array}{l}\text { d.Stomatal } \\
\text { complex }\end{array}$ & $\begin{array}{l}\text { 1.Not available in the present study. } 2 . \text { Obvious } \\
\text { \& available, } \\
\text { Anticlinal walls of subsidiary cells:- } \\
\text { Thickening pattern:- } \\
\text { 1.Uniform, } \\
\text { 2.Slightly buttressed. } \\
\text { 3.Buttressed. } \\
\text { 4.Slightly beaded. } \\
\text { 5.Beaded to buttressed. } \\
\text { 6.Beaded. } \\
\text { Periclinal walls of subsidiary cells:- } \\
\text { Texture:- } \\
\text { 1.Granular. } \\
\text { 2.Smooth. } \\
\text { 3.Slightly reticulate. } \\
\text { 4.Slightly striate. } \\
\text { Stomatal scales:- } \\
\text { Shape:- } \\
\text { 1.Butterfly shaped. } \\
\text { 2.Narrow. }\end{array}$ & $\begin{array}{l}3,4,8,15,20 \text {. } \\
\text { the rest of the taxa. } \\
\text { 1,9,16. } \\
2,12,13 . \\
6 . \\
5,7,18,19,10,11 . \\
14 . \\
17 . \\
1,5,6,9,12,13,16,17,18,19 . \\
2,7,14 . \\
10 . \\
11 . \\
1,7,9,10,17 . \\
2,5,6,11,12,13,14,16,18,19 .\end{array}$ \\
\hline
\end{tabular}


On the taxonomy of Apollonias.Evidence from general aspects and cuticular features of leaf \& fruit.

Table (2b). continued.

\begin{tabular}{|l|l|l|}
\hline Characters & \multicolumn{1}{|c|}{ Attributes } & \multicolumn{1}{|c|}{ Species numbers } \\
\hline e.Epicuticular wax. & Shape:- & 1. \\
& 1.Clusters of tubules and entire platelets. & $2,16$. \\
& 2.Entire platelets. & 5. \\
& 3.Transversely ridged rodlets. ad platelets and rodlets. & 16. \\
& 3.Syntopism of & \\
& 4.Syntopism of platelets and transversely ridged & 6.9. \\
& rodlets. & 7. \\
& 5.Non entire platelets. & 10 \\
& 6.Smooth film. & 12. \\
& 7.Granules, short filaments and small rods. & 13. \\
& 8.Tiny fine filaments. & 18. \\
& 9.Rosettes. & \\
& the rest of taxa \\
\hline
\end{tabular}

Table (2c). Fruit cuticular aspects ( Available only for taxa : 1,6,9,13,18,19).

\begin{tabular}{|c|c|c|}
\hline Characters & Attributes & Species number \\
\hline Overall pattern & $\begin{array}{l}\text { Ruminate. } \\
\text { Reticulate. }\end{array}$ & $\begin{array}{l}1 . \\
6,9,13,18,19\end{array}$ \\
\hline Cell shape & $\begin{array}{l}\text { Highly sinuate. } \\
\text { Undulate. } \\
\text { Slightly undulate. } \\
\text { Slightly undulate to straight. } \\
\text { Straight. }\end{array}$ & $\begin{array}{l}. \\
6 . \\
13 . \\
18 . \\
9,19 .\end{array}$ \\
\hline Thickness & $\begin{array}{l}\text { Thick. } \\
\text { Very thick. }\end{array}$ & $\begin{array}{l}6,9,13,18,19 . \\
1 .\end{array}$ \\
\hline Pattern of Thickness & $\begin{array}{l}\text { Uniform. } \\
\text { Irregular. } \\
\text { Irregular to slightly beaded. } \\
\text { Slightly beaded. }\end{array}$ & $\begin{array}{l}1,9 . \\
18,19 . \\
6 . \\
13 .\end{array}$ \\
\hline Hight & $\begin{array}{l}\text { Raised. } \\
\text { Slightly raised. } \\
\text { Highly raised. }\end{array}$ & $\begin{array}{l}9,13 . \\
6,18,19 . \\
1 .\end{array}$ \\
\hline Texture & $\begin{array}{l}\text { Smooth. } \\
\text { Granular to papillose. } \\
\text { Granular with glandular bodies prominent. }\end{array}$ & $\begin{array}{l}1 . \\
6 . \\
9,13,18,19\end{array}$ \\
\hline
\end{tabular}



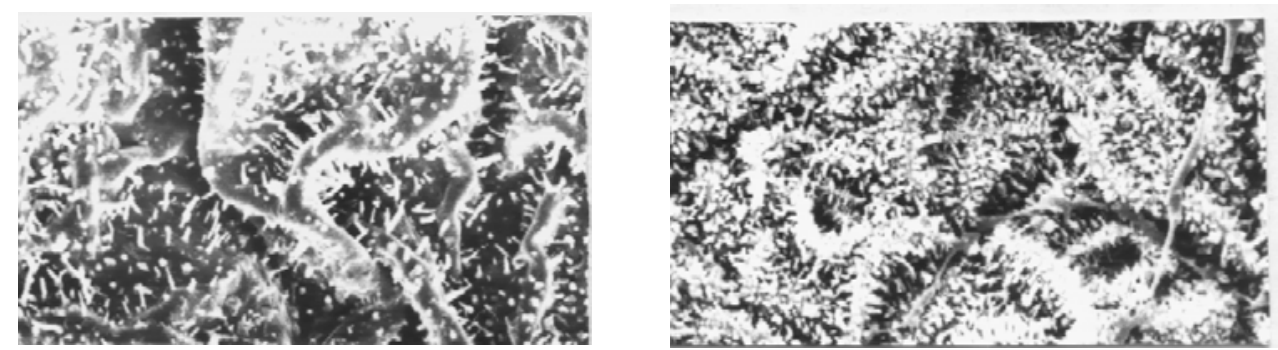

a

$10 \mu m$

d
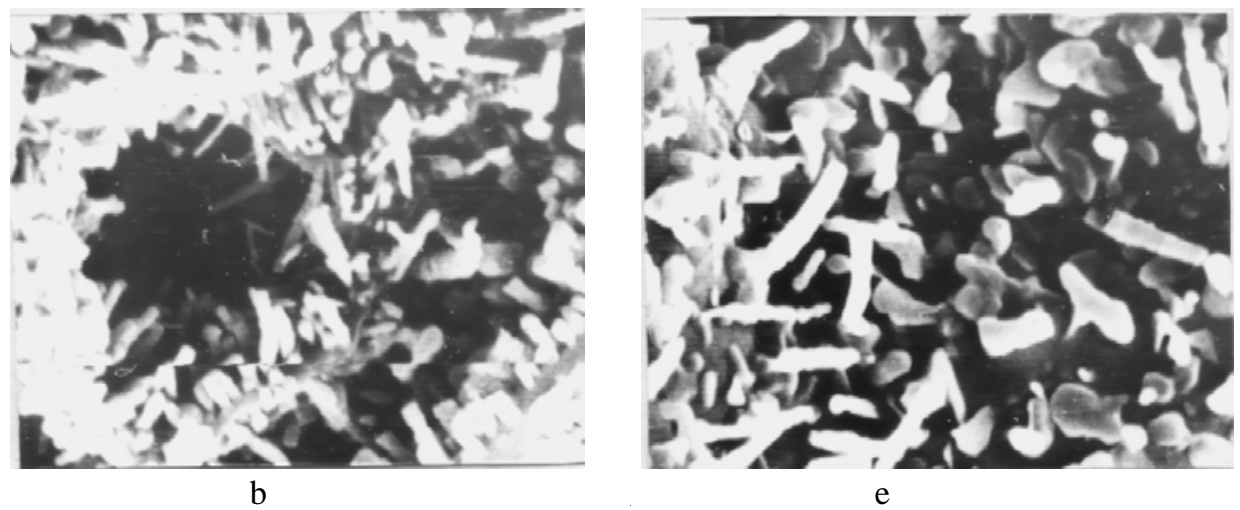

$\sin$

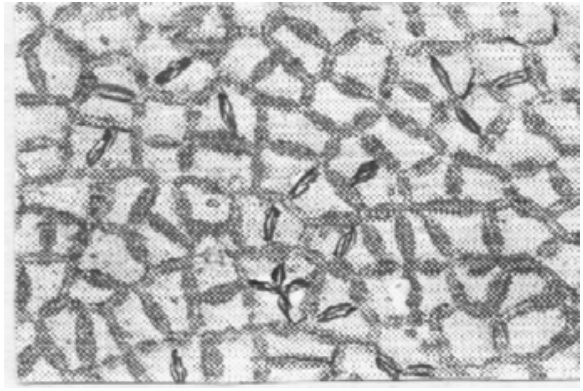

C

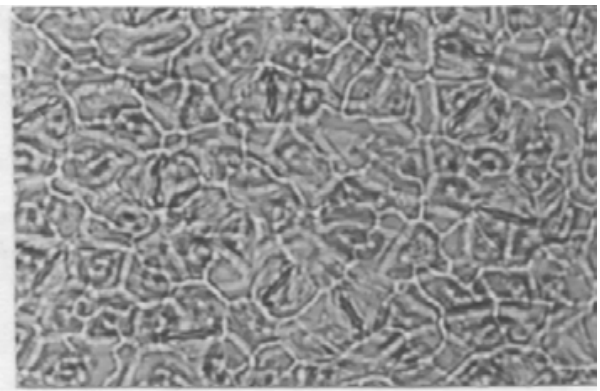

f

Figure 2. Leaf cuticular aspects of Apollonias barbujana: a. SEM of upper epidermis, b. SEM of epicuticular wax (upper epidermis), c. LM of upper epidermis, (x 320), d. SEM of lower epidermis, e. SEM of epicuticular wax (lower epidermis), f. LM of lower epidermis showing stomata, (x 320). 


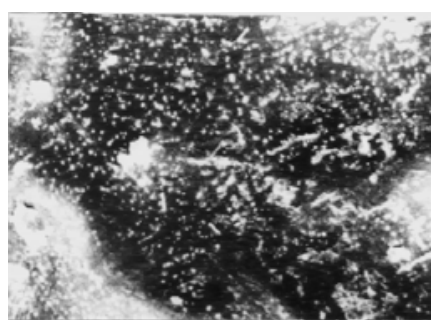

g
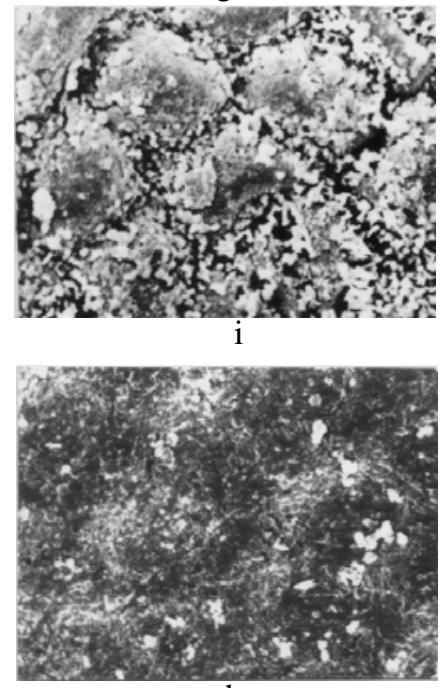

$\mathrm{k}$

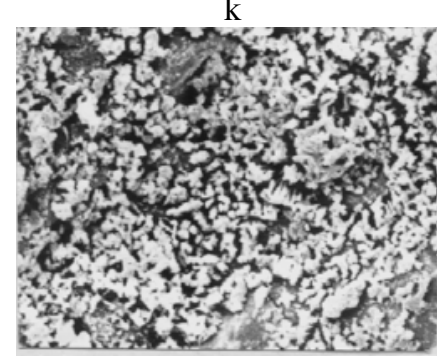

m

$10 \mu \mathrm{m}$

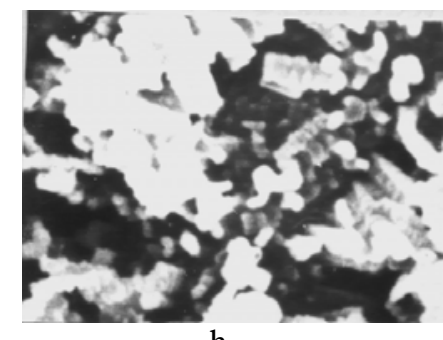

h
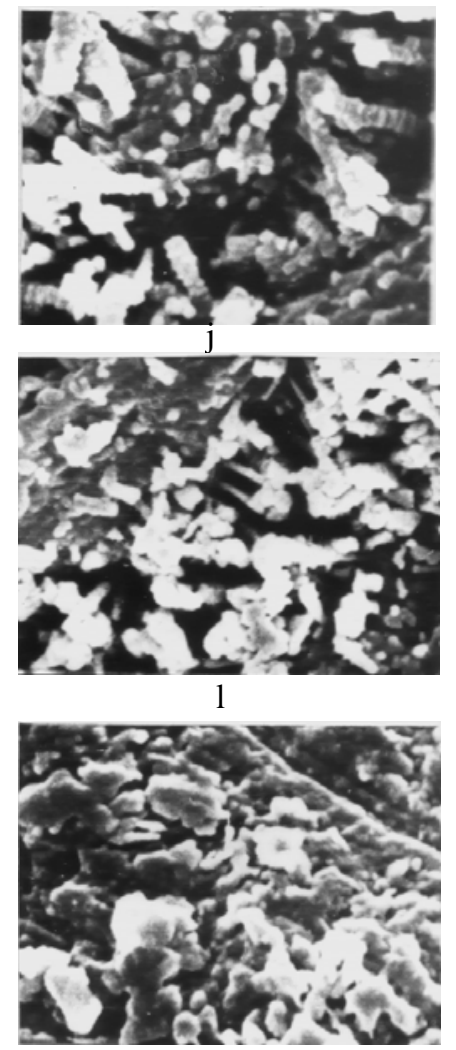

$\mathrm{n}$

$\mathbf{S H}$

Figure 2. continued. Cinnamomum camphora: g. SEM of upper epidermis, h. SEM of epicuticular wax (upper epidermis), i. SEM of lower epidermis, j. SEM of epicuticular wax (lower epidermis). Cinnamomum glanduliferum: k. SEM of upper epidermis, .l. SEM of epicuticular wax (upper epidermis), m. SEM of lower epidermis, n. SEM of epicuticular wax(lower epidermis). 


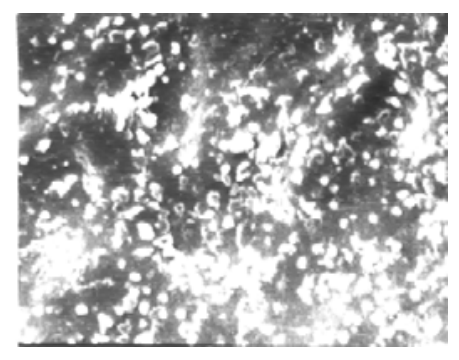

0

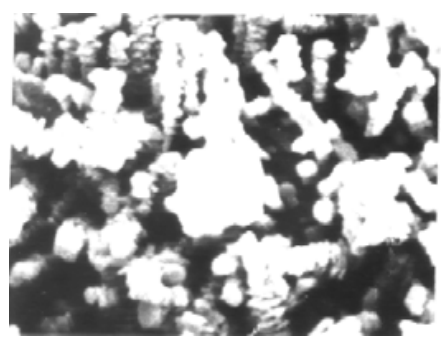

$\mathrm{q}$
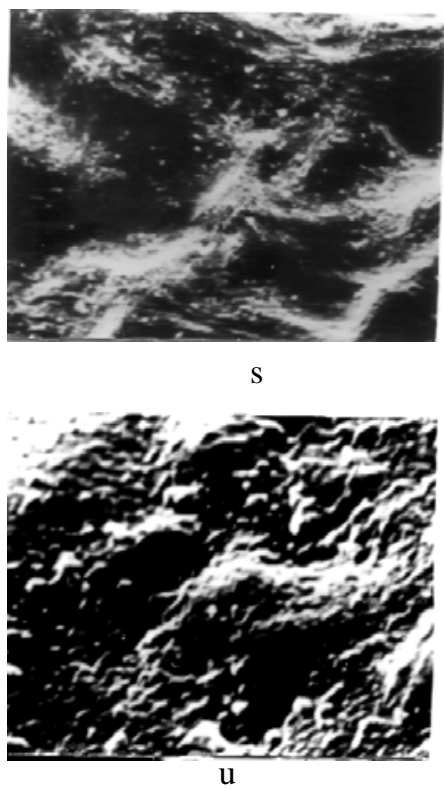
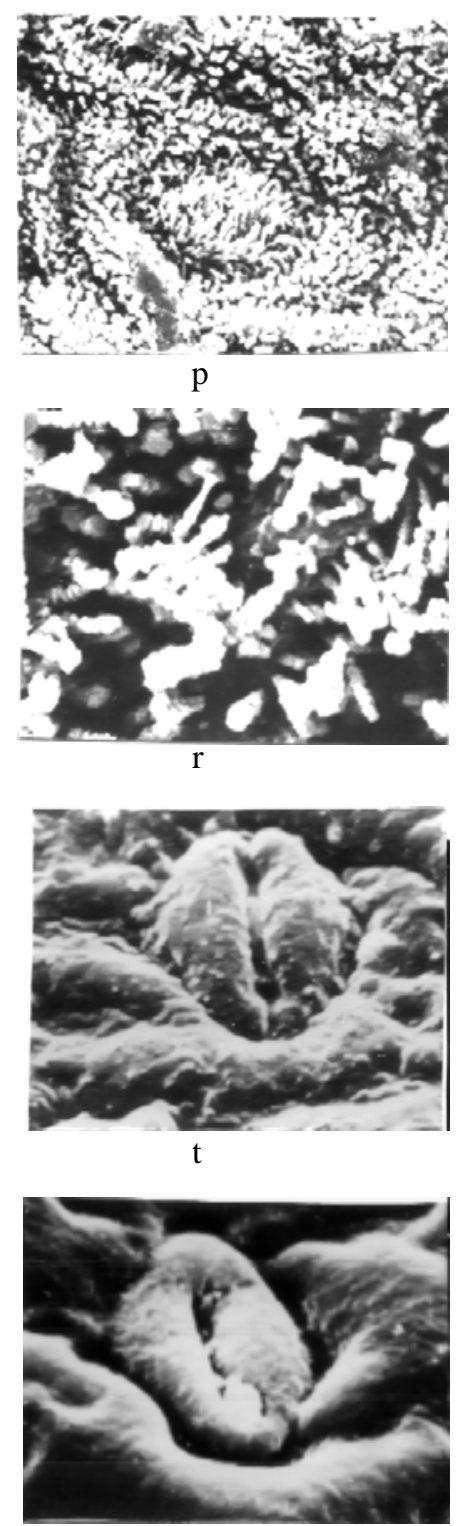

$\mathrm{V}$

Figure 2, cont. Cinnamomum verum: o. SEM of upper epidermis, (x 1000), p. SEM of epicuticular wax, upper epidermis, (x 1000), q. SEM of lower epidermis, (x 1000), r. SEM of epicuticular wax, lower epidermis. Laurus azorica: s. SEM of upper epidermis (x 1000), t. SEM of lower epidermis showing the stomatal complex and epicuticular wax, (x 1000). Laurus nobilis: u. SEM of upper epidermis, (x 1000), v. SEM of lower epidermis showing the stomatal complex and epicuticular wax, (x 1000). 


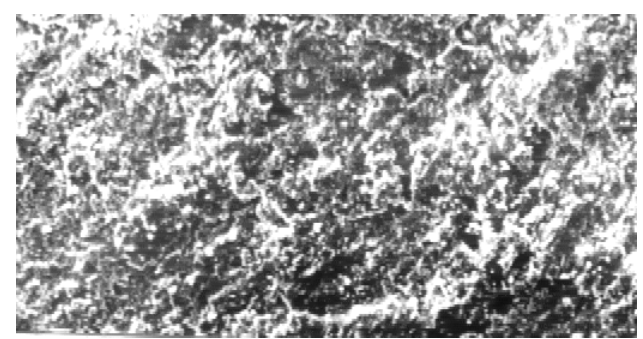

$\mathbf{W}$

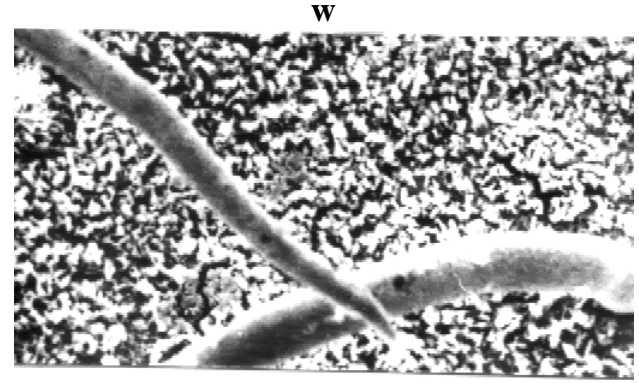

$\mathbf{y}$

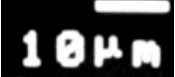

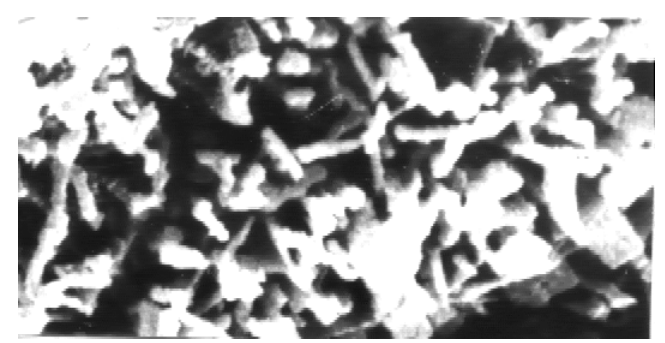

$\mathbf{x}$

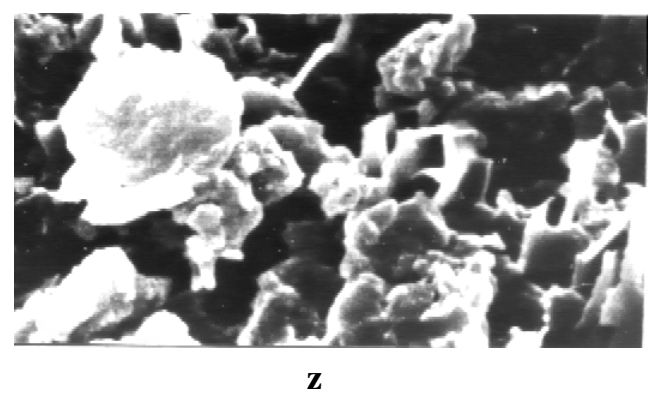

SMn

Figure 2, continued. Persea americana: w. SEMof upper epidermis, x. SEM of epicuticular wax (upper epidermis), y. SEM of lower epidermis showing long pointed trichomes, z. SEMof of epicuticular wax (lower epidermis).

\section{Discussion}

Several suprageneric classifications of the Lauraceae were proposed (Nees, 1836; Meissner, 1864; Bentham, 1880; Mez, 1889; Pax, 1891; Kostermans, 1957; Hutchinson, 1964; Richter, 1981; Rohwer, 1993 and van der Werff \& Richter, 1996) yet the results of the different studies have been very different depending on the author's opinion and on the reliability of the used characters (Rohwer, 2000).

In most suprageneric classifications of the Lauraceae, Apollonias was placed in a group more or less corresponding to the Perseeae (sensu Kostermans, 1957 and Rohwer, 1993). This was mainly due to its possessing a paniculate ex-involucrate inflorescence. However, Richter (1981) utilizing data from wood and bark anatomy; reported that Apollonias possessed certain links with some genera of the Laureae particularly Laurus L., Lindera Thunb., and Neolitsea Merr. on one hand, and certain genera of the Perseeae on the other hand. Moreover, he placed Apollonias diagramatically as standing the same distance apart from the two groups. 
M. H. A Loutfy

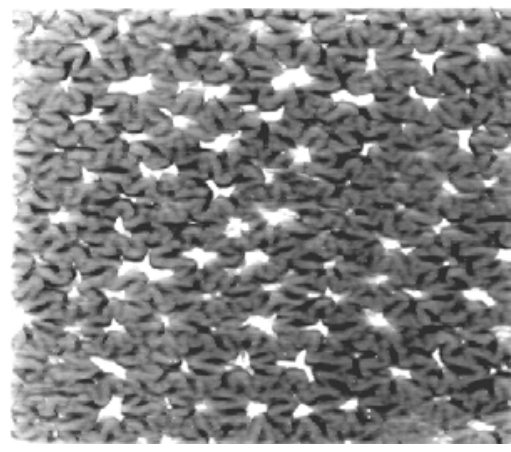

1

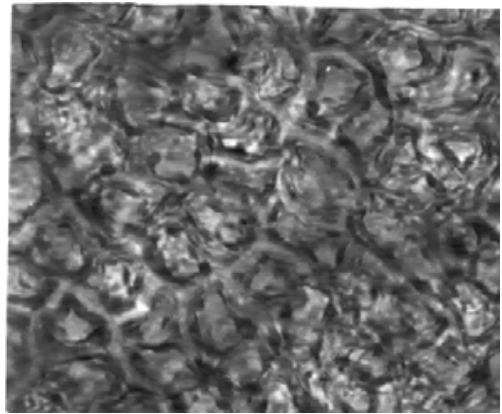

3

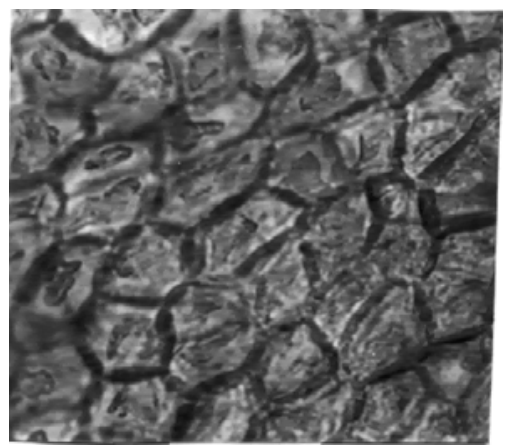

5

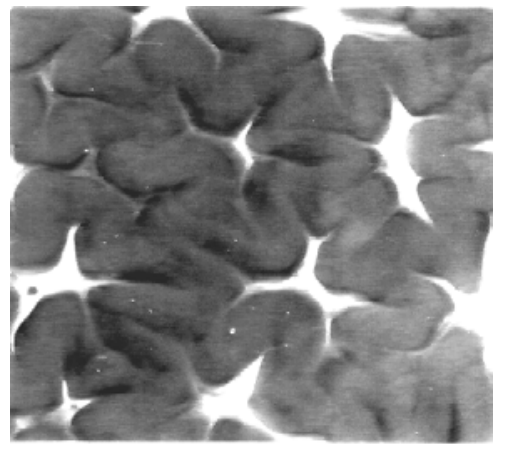

2

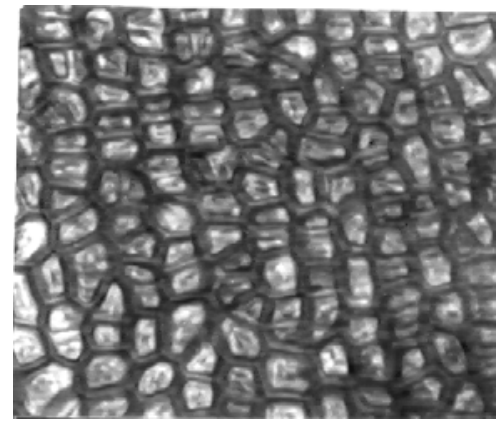

4

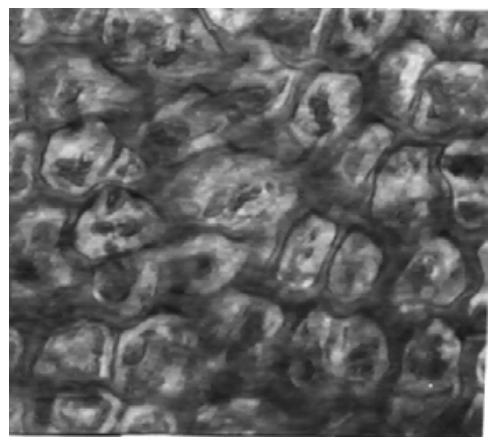

6

Figure 2, continued. Fruit cuticular aspects: 1- Apollonias barbujana (x=126) 2- Apollonias barbujana ( $\mathrm{x}=700), 3-$ Cinnamomum glanduliferum $(\mathrm{x}=350)$, 4- Cinnamomum verum $(\mathrm{x}=350)$, 5- Laurus nobilis $(\mathrm{x}=350) 6$ - Persea americana $(\mathrm{x}=350)$. 
In the present study, a survey of the general macromorphological and floral aspects in 20 taxa of the Lauraceae representing both the Laureae and Perseeae, did not locate any synapomorphic characters that may link Apollonias to any of the studied Laureae (Laurus, Lindera, Litsea and Neolitsea). The few common characters as the penninerved venation of leaves, the two locular anthers and the flat receptacle were also represented in the Perseeae (van der Werff \& Richter, 1996). However, Apollonias possessed some characters of its own, as the fruit that is clasped at its base by the persistent perianth segments resembling a pseudo cupule (Table 2 a). The same feature was also reported to be present in the related Phoebe (Rohwer, 1993). As to the cuticular aspects of the leaf and fruit, Apollonias was shown to possess certain unique features that differentiated it from the other studied taxa, among these is the presence of dense clusters of hollow tubular epicuticular waxes on both surfaces of the leaf (Fig.2 a,b,d,e\& Table 2 b) and its fruit possessing extremely thick and highly sinuate anticlinal walls (Fig.3\& Table 2c). Unfortunately, no material (either original or compiled was available from Alseodaphne, Dehaasia, Phoebe and Nothaphoebe which were reported by several authors to be very close to Apollonias (Bentham, 1880 and Kostermans, 1957, 1973 a\&b). The study also revealed that Apollonias shares exclusively some features with members of the Laureae (Laurus species) as the highly raised, thick and striated anticlinal walls of the upper epidermal cells of the leaf, (Table $2 \mathrm{~b}$ ).

The phenogram constructed according to the combination of 26 macromorphological and floral aspects that are /or were considered to be of taxonomic significance in the different suprageneric classifications of the family; clearly grouped Apollonias (as was expected) with members of the Perseeae, with close affinities with Beilschmiedia (2) \& Persea $(18,19)$ Fig.4a. This result agreed to some extent with Kostermans's, who showed that Apollonias was closely related to Persea through Phoebe and that Persea in turn was related to Beilschmiedia. Yet Cryptocarya (10) and Endiandra (11) occupied a somewhat isolated position, the former split from the rest of the studied taxa at a dissimilarity level of 1.9 mainly due to its possessing only three fertile stamens, while the latter split at 1.73 mainly due to its possessing a deeply urceolate receptacle and a fruit completely enclosed in the accrescent receptacular tube (Table 2 a).

The phenogram constructed according to the combination of 88 characters of leaf cuticular features showed that Cryptocarya (10) occupied an isolated position as it split off early from the rest of the studied taxa at the dissimilarity level of 1.8. Apollonias splitted from the remaining taxa at 1.59 (Fig. 4b).

However, the phenogram constructed according to the combination of 114 characters from both leaf cuticles and macromorphology again showed the isolation of Cryptocarya and the spliting of Apollonias from the remaining taxa at the dissimilarity level of 1.57 (Fig. 4c). Rohwer (1993) suggested that Apollonias should be included in Phoebe, as the two genera differed only in the number of anther locules (two in Apollonias and four in Phoebe), but again no cuticular material was available from Phoebe to make a comparison. The same author also stated in (2000) that Apollonias is closly related to Persea according to evidence from mat K. sequences. A similar result was reached at by Kamel \& Loutfy (in Press) by utilizing data from SDS-PAGE of seed protein profiles in both taxa. 


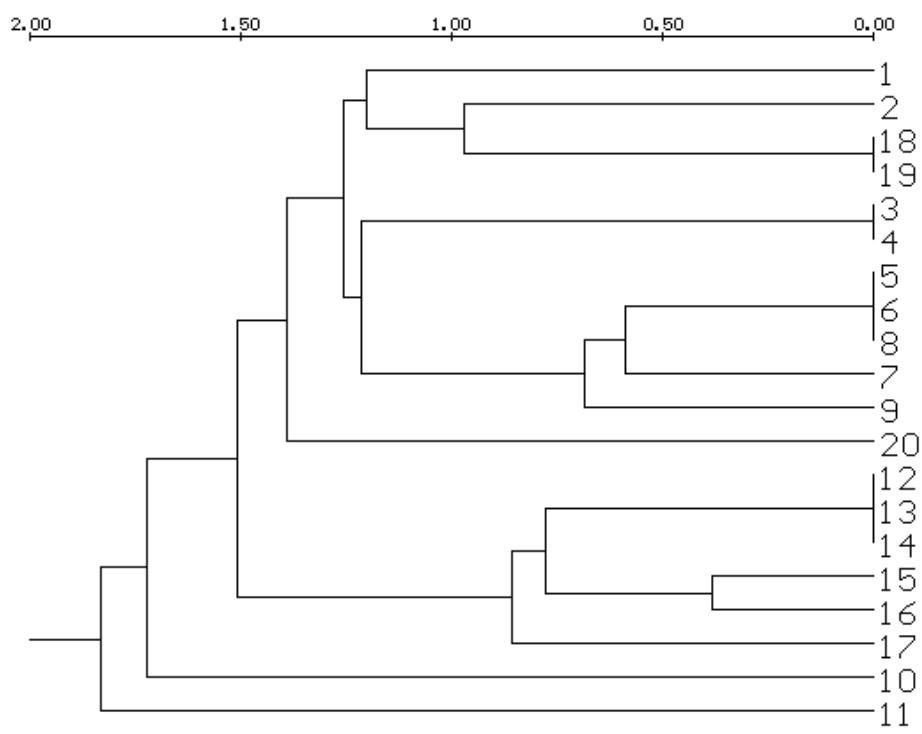

Figure (4a). UPGMA - phenogram illustrating the relationships between the studied taxa based on the coding of 26 attributes from macromorphology. (Taxa are numbered as in Table (1).

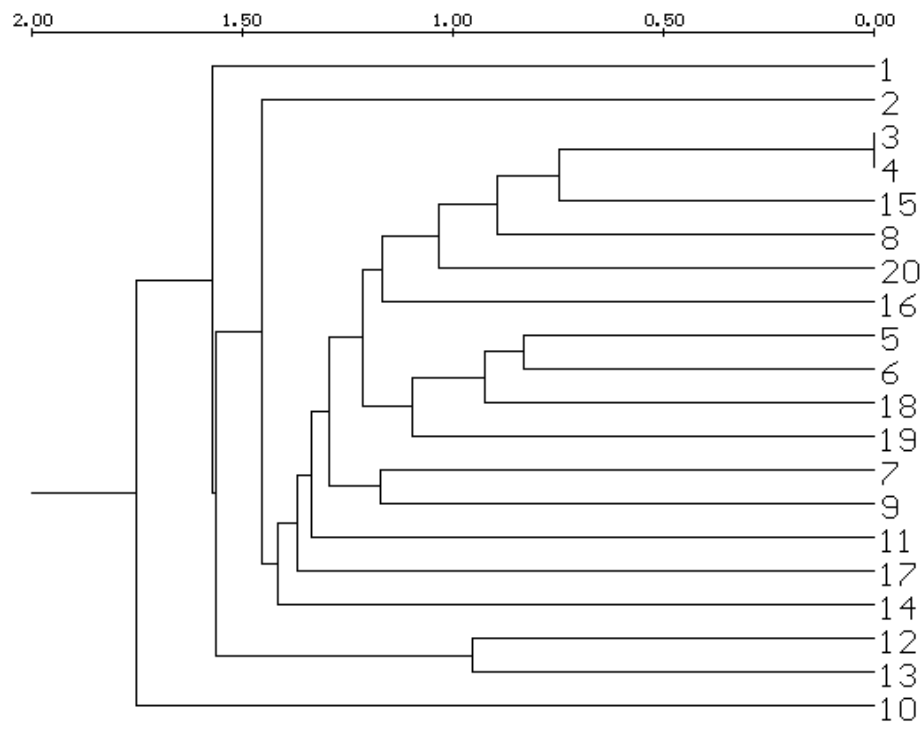

Figure (4b). UPGMA - phenogram illustrating the relationships between the studied taxa based on the coding of 88 attributes obtained from leaf cuticular features. (Taxa are numbered as in Table (1). 


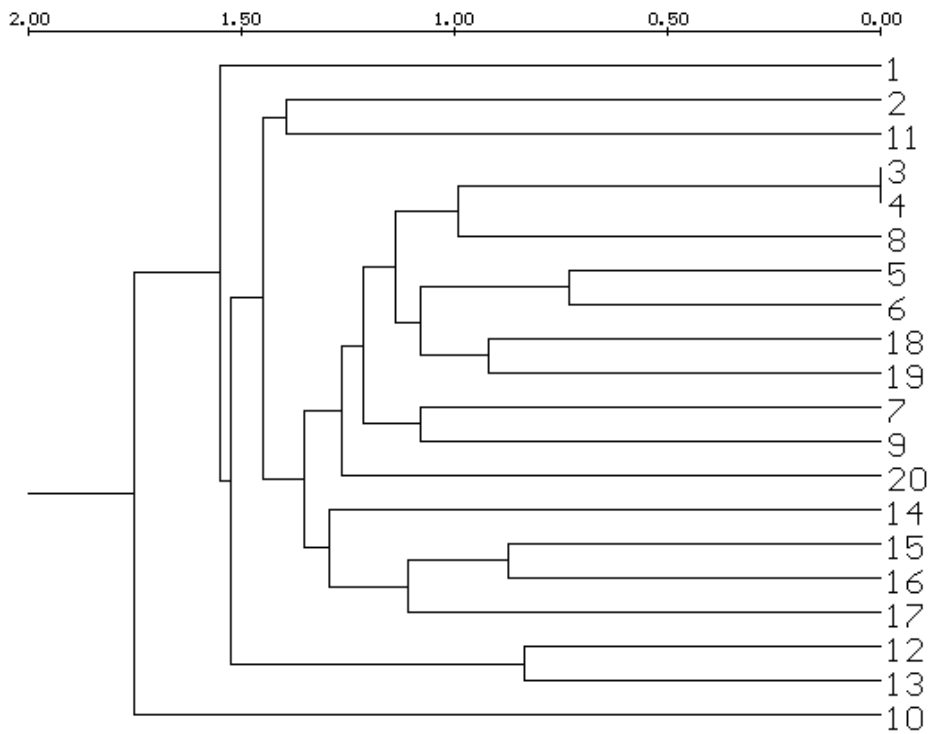

Figure (4c). UPGMA - phenogram illustrating the relationships between the studied taxa based on the coding of 114 attributes from macromorphology and leaf cuticular features. (Taxa are numbered as in Table (1).

The present study showed that Apollonias barbujana (cav.)Bornm., a Macaronesian relict, seems to occupy a relatively isolated position, with affinities with both the Laureae and the Perseeae as stated earlier by Richter (1981). However, this notion comes only from structural evidence (Wood and bark anatomy by Richter 1981 and cuticular features in the present study); for a close relationship of Apollonias with Persea was achieved when utilizing different sets of data as mat $\mathrm{K}$ sequences and / or SDS-PAGE of seed protein profiles (Rohwer, 2000 and Kamel \& Loutfy in Press). However, the overlap and generally uniform distribution of cuticular features among the studied taxa of the Laureae and Perseeae (sensu Rohwer, 1993 ) or the Cryptocaryeae, Laureae and Perseeae sensu Van der Werff \& Richter, (1996) suggest that the current suprageneric classifications of the Lauraceae might need a future revision, a fact that was realized by Rohwer (2000) who stated that the separation of tribes in the Lauraceae by the type of inflorescence (involucrate in the Laureae, non-involucrate in the Perseeae) was not supported by molecular evidence. Moreover large genera in the Perseeae as Cinnamomum Schaeff sensu lato (350 species , Mabberley, 1997) were shown in the present study to be distributed among three groups (Fig. 3b\&c). The most remarkable, were that in two of these groups, genera of the Laureae as Lindera, Neolitsea and Litsea were included. This may give extra support to the paraphyly of Cinnamomum as suggested by Christophel et al., (1996a) and the strictly monophyletic nature of the Lauraceae (Renner, 1999).

A thorough revision of the family at the generic and tribal level is needed (Rohwer, 2000). It is worth mentioning that Cinnamomum Burm (s.str) was considered by Baillon (1872) and several authors to be very near to Apollonias as regarding its floral 
structure. The phytochemical data give extra evidence for the isolated and relict nature of Apollonias, a specific irregular phenyl propanoid 2-(3-methoxy-4-hydroxyphenyl)-1,3propanediol, in addition to another two other specific lignans were isolated from the leaves of A. barbujana (Perez et al., $1995 \mathrm{a} \& \mathrm{~b}$ ). As to the macromorphological vegetative characters, Apollonias barbujana often showed a striking superficial resemblance to Laurus species (Fig.1) and is distinguished only by the absence in the former taxon of gland-like depressions on the midrib of the lower leaf surface. Herbarium specimens of both taxa are/ or were often confused (Ferguson, 1974). This phenomenon (mimicry) is a widely distributed angiosperm character that has been generally underestimated by taxonomists, but might be of some value (Good, 1962). Moreover, Apollonias leaves are frequently marked with wart-like protuberances (domatia) caused by the mite Eriophytes barbujanae Carmona, which is specific to this tree (Short, 1994).

Finally, the exclusive use of cuticle characters within the Lauraceae has achieved a considerable degree of success on material from different localities: Ow et al., (1992) on Taiwan species; Christophel et al., (1996a) mainly on Australian and some south American species; Christophel \& Rowett, (1996b); Li \& Christophel (2000) on Australian species and Loutfy (2000) on Laurus species from the Mediterranean region and Macaronesia).

The present study, using cuticular aspects, shows that cuticular features can be a promising criterion in the delimitation of genera and species within the family Lauraceae s.l..

\section{Acknowledgements}

Thanks are due to Dr. Azza Shehata, Assistant Prof. of Botany, Faculty of Science. Alexandria Univ. for kindly photographing by the SEM at the Central Laboratory of Faculty of Science. Thanks are also due to Mrs. Tereeza Labib - Orman Botanical garden for providing the local material of the Lauraceae and to Alicia Roca, Jardin Botanico Canario for providing herbarium specimens and seeds of Apollonias barbujana.

\section{References}

Baillon H. 1872. The natural history of plants. Translated by Hartog, M. M. vol. II. London, L. Reeve \& Co. 426-480.

Bailey L.H. \& Bailey E.Z. 1976. Hortus Third. A Concise Dictionary of Plants Cultivated In The U.S. \& Canada. 'Revised by Staff of the L.H.Bailey Hortorium' The Macmillan Publishing Company New York.

Bandulska H. 1926. On the cuticles of some fossil and recent Lauraceae. J. Linn. Soc. Bot., 47: 383-425.

Barbero M., Benabid A., Peyre C. \& Quezel P. 1981. Sur la presence au Maroc de Laurus azorica (Seub.) Franco. Anales Jard. Bot. Madrid. 37: 467-472.

Barthlott W. 1981. Epidermal and seed surface characters of plants: Systematic applicability and some evoltionary aspects. Nord. J. Bot. 1: 345-355.

- 1990. Scanning electron microscopy of the epidermal surface in plants. In D. Claugher (ed.). Scanning Electron Microscopy in Taxonomy and Functional Morphology. Systematics Association Special Volume No 41. Clarendon Press, Oxford Pp. 69-83. 
Barthlott W., Neinhuis C., Cutler D., Ditsch F., Meusel I., Theisen I. \& Wilhelmi H. 1998. Classification and terminology of plant epicuticular waxes. Bot. Journal of the Linnean Society. 126: 237-260.

Bentham G. 1880. Laurineae. In Bentham, G. \& Hooker, J.D. (ED.) Genera Plantarum. L. Reeve \& Co., Williams \& Norgate. London. Pp. 146-168.

Bornmuller J. 1903. Ergebnisse zweier botanischer Reisen nach Madeira und der Canarischen Inseln. Bot. Jahrb., 33: 387-492.

Christophel D. C., Kerrigan R. \& Rowett A. I. 1996a. The use of cuticular features in the taxonomy of the Lauraceae. Annals of the Missouri Bot. Garden, 83(3): 419-432.

, \& Rowett A. I. 1996b. Leaf and cuticle Atlas of Australian leafy Lauraceae. Flora of Australia supplementary series number 6. Canberra, pp. 1-217.

Farr E., Leussink J.A. \& Stafleu F.A. 1979. Index Nominum Genericorum (Plantarum). Vol (I) Bohn, Scheltema \& Holkema, Utrecht, etc.

Ferguson D. K. 1971. The Miocene flora of Kreuzau, Western Germany. I. The leaf remains. Verh. K. Ned. Akad. Wet. (afd. Natuukunde, Tweede Reeks), 60: 1-297.

1974. On the taxonomy of recent and fossil species of Laurus (Lauraceae). Bot. J. Linn. Soc., 68: 51-72.

Graybeal A. 1998. Is it better to add taxa or characters to a difficult phylogenetic problem? Sys. Biol., 74: 9-17.

Good R. 1962. Features of Evolution in the Flowering Plants. Longmans. Pp. 325-352.

Hill R. S. 1986. Lauraceous leaves from the Eocene of Nerriga, New South Wales. Alcheringa, 10: 327-351.

Hutchinson J. 1964. The genera of flowering plants (Dicotyledonae), vol. I. Clarendon press. Oxford.

Hyland B.P.M. 1989. A Revision of Lauraceae in Australia (excluding Cassytha). Austral. J.Syst.Bot. 2:135-367.

International Plant Names Index (IPNI) Officially Launched (2000) http:// www. Ipni.org. Mark Jackson Applications Development Manager, Royal Botanic Gardens,Kew.

Kamel E.A. \& Loutfy M.H.A. 2001. The significance of cuticular Features, Petiole Anatomy and SDS-PAGE in the Taxonomy of the Lauraceae. Pakistan Journal of Biological Sciences (In Press).

Kasapligil B. 1951. Morphological and ontogenetic studies of Umbellularia californica Nutt. and Laurus nobilis L. Univ. Calif. Publs. Bot. 25: 115-240.

Kostermans A. J. G. H. 1957. Lauraceae, Common Forest. Res. Inst. 51: 1-64.

1973a. A Synopsis of Alseodaphne Nees (Lauraceae). Candollea 28: 93-136.

Kostermans A. J. G. H. 1973b. A Synopsis of the genus Dehaosia Bl. (Lauraceae). Motanische Jahrbucher fur Systematik. Pflanzengeschichte und Pflanzengeographie 93:424-480.

Li. J. \& Christophel D.C. 2000. Systematic relationships within the Litsea complex (Lauraceae): a cladistic analysis on the basis of morphological and leaf cuticle data. Austral. Syst.Bot. 13 (1): 1-13.

Loutfy M. H. A. 2000. On the delimitation of Laurus species (Lauraceae). Proc. $1^{\text {st }}$ Int. Conf. Biol. Sci. (ICBS), Fac. Sci., Tanta Univ.7-8 May 2000, (1): 71-91.

Mabberley D. J. 1997. The plant-book, A portable dictionary of the vascular plants. Cambridge University press. P.393.

Meissner C. F. 1864. Lauraceae in A. P. de Candolle, Prodromus systematis regni vegetabilis. 15. Paris: Masson. Pp: 1-260, 516.

Mez. C. 1889. Lauraceae Americanae Jahrb. Konigl Bot. Gart. Berlin. 5:1-556. 
Nees von Esenbeck C. G. 1833. Laurin. Expos., 10. In International Plant Names Index (IPNI) Officially Launched (2000) http:// www. Ipni.org. Mark Jackson Applications Development Manager, Royal Botanic Gardens,Kew.

1836. Systema Laurinarum, Berlin. Pp: 670, 696.

Ow C., Hsiao J.\& Liao C. 1992. Cuticle micromorphology of Cinnamomeae (Lauraceae) from Taiwan. Bull. Exp. Forest Natl. Taiwan. Univ. 14:1-30.

Pax F. 1889. Lauraceae in A. Engler and K. Prantl (editors) Die naturlichen pflanzenfamilien, vol. III. Engelmann Leipzig.

Perez C.. Almonacid L.N., Trujillo J.M., Gonzalez A.G., Alonso S.J. \& Navarro E. 1995a. A new irregular phenyl propanoid from Apollonias barbujana Planta - Medica 61: 6, 535-536. 1995b: Lignans from Apollonias barbujana Phytochemestry, 40: 5, 1511-1513.

Press J. R. \& Short M. J. 1994. (editors). Flora of Madeira. HMSD, Publication center, London.

Renner S. 1999. Circumscription and phylogeny of the Laurales: evidence from molecular and morphological data. Am. J. Bot., 86: 1301.

Richter H. G. 1981. Anatomie des sekundaren xylems und der rinde der Lauraceae. Sonderb; Naturwiss. Vereins. Hamburg, 5: 1-148.

Rohlf F. J. 1993. Ntsys-pc, Numerical taxonomy and multivariate analysis system. New York, Exeter pub., Ltd.

Rohwer J. G. 1993. Lauraceae. In Kubitzki, K., (ed.): The families and genera of vascular plants. Springer. Berlin, Heidelberg, New York.

1994. A note on the evolution of the stamens in the Laurales with emphasis on the Lauraceae. Botanica Acta. (107): 2, Pp: 103-110.

2000. Toward a phylogenetic classification of the Lauraceae. Evidence from mat K sequences, Sys. Bot., 25 (1): 60-71.

-, Richter H. G. \& H. van der Werff, 1991. Two new genera of neotropical Lauraceae and critical remarks on the generic delimitation. Ann. Missouri Bot. Gard. 78: $388-400$.

Short M.J. 1994. Lauraceae In Press, J.R., \& Short, M.J., 1994,(ed) Flora of Madeira. HMSD Publication Centre. London. Pp. 100-102.

Stearn W. T. 1992. Botanical Latin $4^{\text {th }}$ Edition. Timber Press, Portland, Oregon.

Van der Werff H. 1991. A Key to the genera of Lauraceae in the New World. Ann. Missouri. Bot. Gard. 78: 377-387.

Van der Werff H. \& Richter H. G. 1996. Toward an improved classification of the Lauraceae . Ann. Missouri Bot. Gard. 83: 409-418.

Wikinson H. P. 1979. The plant surface (Mainly Leaf). In Metcalfe, C. R. and Chalk, L., 1979. Anatomy of the dicotyledons. Sec. Ed. Vol. (1) Clarendon Press. P: 97-166. 